\title{
Pengaruh Integrasi Tanaman dan Ternak Sapi Terhadap Peningkatan Pendapatan dan Produktivitas Petani (Studi Kasus : Petani Kentang di Kecamatan Harian, Kabupaten Samosir)
}

\author{
Lyndon Paruliana, Kiki Pagar S.M. Munthe ${ }^{\mathrm{b}}$, Ruth Dameria Haloho ${ }^{\mathrm{c}}$ \\ ${ }^{a}$ Fakultas Pertanian Universitas Quality,Berastagi, Kabupaten Karo-Sumatra Utara, Indonesia. Email:
} lyndonparuliannainggolan66@gmail.com

${ }^{b}$ Fakultas Pertanian, Universitas Quality,Berastagi, Kabupaten Karo - Sumatera Utara, Indonesia. Email: kikimunthe@ gmail.com ${ }^{c}$ Fakultas Pertanian, Universitas Quality,Berastagi, Kabupaten Karo - Sumatera Utara, Indonesia. Email: ruthdameria@gmail.com

\section{Article Info}

\section{Article history:}

Received 25 Februari 2019

Received in revised form 20 Maret 2019 Accepted 19 April 2019

DOI:

https://doi.org/10.32938/ag.v4i2.694

Keywords:

Kentang

Integrasi

Ternak Sapi

Petani

\section{Abstrak}

Penelitian ini bertujuan untuk mengetahui pengaruh integrasi tanaman dan ternak sapi terhadap produktivitas tanaman dan peningkatan pendapatan petani di Kecamatan Harian, Kabupaten Samosir. Penelitian ini dilaksanakan di Desa Partungko Naginjang, Janji Martahan, dan Siparmahan di Kecamatan Harian, Kabupaten Samosir. Metode Penelitian adalah studi kasus. Analisis data yang digunakan adalah uji $\mathrm{t}$ test. Kesimpulan dari penelitian ini adalah integrasi tanaman dan ternak sapi berdampak signifikan terhadap peningkatan produktivitas lahan dengan tanaman kentang per musim tanam, petani peserta integrasi lebih tinggi dibandingkan dengan petani bukan peserta, dengan perbedaan produktivitas lahan adalah sebesar 0,99 ton per Ha dan integrasi tanaman dan ternak sapi berdampak signifikan terhadap peningkatan pendapatan petani. Rata-rata pendapatan petani peserta integrasi per musim tanam lebih tinggi dibandingkan pendapatan petani bukan peserta, dengan perbedaan pendapatan sebesar Rp. 11.562.968 per Ha. Kepada para petani yang belum memanfaatkan integrasi tanaman dan ternak sapi, diharapkan ikut serta sebagai peserta karena memberikan peningkatan pendapatan dan produktivitas petani.

\section{Pendahuluan}

Dalam peningkatan kesejahteraan petani dalam pembangunan pertanian merupakan salah satu sektor yang cukup strategis dalam perekonomian Indonesia terutama dalam produksi pangan, pertumbuhan GDP, substitus impor, penyediaan lapangan kerja, dan kesempatan berusaha. Pembangunan sektor pertanian yang meliputi perkebunan, peternakan, kehutanan dan lain-lain dilakukan melalui pendekatan sistem dan usaha agribisnis yang berdaya saing, berkerakyatan, berkelanjutan, terdesentralisasi, serta mencakup aspek hulu, budidaya, aspek hilir, maupun komponen pendukungnya (Poltak et al., 2015).

Pembangunan pertanian bertujuan untuk meningkatkan produksi pertanian guna memenuhi konsumsi dalam negeri dan meningkatkan kontribus devisa dari sektor pertanian. Pembangunan pertanian di Indonesia mempunyai peranan yang penting dalam perekonomian negara. Sektor pertanian mempunyai efek pengganda ke depan dan ke belakang yang besar melalui peningkatan input-output-outcome antar industri, konsumsi dan investasi (Departemen Pertanian, 2005)

Pembangunan sektor pertanian tidak dapat lagi dilakukan dengan caracara lama, harus diubah sejalan dengan makin besarnya tantangan dan perubahan lingkungan strategis, baik yang datang dari dalam maupun dari luar Sistem pertanian yang tanpa memperhatikan kaidah-kaidah keseimbangan ekologi merupakan bagian dari upaya perusakan lingkungan hidup. Pertanian ramah lingkungan dapat dikembangkan salah satunya dengan sistem pertanian terpadu tanaman dan ternak (Lubis , 2012).

Menurut Salikin (2003) sistem pertanian berkelanjutan dapa dilaksanakan dengan menggunakan empat model macam sistem, yaitu sistem pertanian organik, sistem pertanian terpadu,sistem pertanian masukan lua rendah dan sistem pengendalian hama terpadu. Konsep sistem pertanian terpadu adalah konsep pertanian yang dapat dikembangkan untuk lahan terbatas maupun lahan luas (Behera et al., 2008). Pada lahan terbatas atau lahan sempit yang dimiliki petani, konsep ini sangat tepat dikembangkan dengan pola intensifikasi lahan. Lahan sempit akan memberikan produksi maksimal tanpa ada limbah yang terbuang percuma Sedangkan untuk lahan luas konsep ini akan menjadi suatu solusi mengembangkan pertanian agribisnis yang lebih menguntungkan (Tracy and Davis, 2009).

Konsep pertanian terpadu ini perlu digalakkan, mengingat sistem ini ramah lingkungan, juga mampu meningkatkan usaha peternakan (Hendrikson et al., 2008). Konsep integrasi ternak dalam usahatani tanaman, baik itu tanaman perkebunan, pangan atau hortikultura adalah menempatkan dan mengusahakan sejumlah ternak, tanpa mengurangi aktifitas dan produktifitas tanaman. Bahkan keberadaan ternak ini harus dapat menigkatkan produktivitas tanaman sekaligus dengan produksi ternaknya. Sebagai akibatnya adalah keluarga petani yang mengusahakan pertanian terpadu tanaman dan ternak, harus menguasai teknik pemeliharaan dan pemanfaatan ternak secara baik (Direktorat Budidaya Ternak Ruminansia, 2010)

Pembangunan peternakan yang merupakan bagian dari pembangunan pertanian memiliki arti penting bagi ketahanan pangan dan upaya peningkatan kualitas sumber daya manusia Indonesia. Fungsi protein hewani sangat menentukan dalam mencerdaskan manusia karena kandungan asam aminonya tidak dapat tergantikan (irreversible) oleh bahan makanan lainnya. Salah satu sumber protein hewani tersebut didapat dari daging ternak. Ternak sapi potong merupakan salah satu jenis ternak ruminansia yang penting dalam memasok kebutuhan daging asal ternak (Poltak et al., 2015).
Dalam sistem integrasi ini akan terjadi simbiosis mutualisme dimana masing-masing pihak baik ternak sapi maupun tanaman sama-sama mendapa manfaat dengan adanya sistem integrasi ini. Dalam sistem tersebut dapa memberi manfaat sebagai berikut menjadi tenaga ternak bagi petani, menghasilkan daging (untuk sapi potong), menghasilkan anak sapi (dari sap induk), menghasilkan susu (dari sapi perah) dan menghasilkan pupuk kandang.

Pendapatan petani yang menerapkan sistem integrasi dan tidak integrasi sapi dengan tanaman tentu berbeda. Hal ini karena petani yang menerapkan sistem integrasi akan memperoleh penerimaan yang berasal dari 2 (dua) usaha yaitu usahatani tanaman kentang dan ditambah penerimaan yang berasal dari usaha ternak sapi yang dimiliki. Sedangkan petani yang belum menerapkan sistem integrasi hanya memperoleh penerimaan yang berasal dari usahatani tanaman kentang. Sistem integrasi ternak sapi dan tanaman merupakan salah satu cara efektif meningkatkan produktivitas pangan berwujud nabati dan hewani.

Manfaat langsung yang diperoleh petani dari mengintegrasikan tanaman dengan ternak sapi, yakni hijauan dan limbah tanaman kentang dapat dimanfaatakan untuk menambah kebutuhan pakan ternak sapi. Sedangkan kotoran hewan ternak sapi dapat dijadikan pupuk kandang untuk meningkatkan kesuburan tanaman kentang (Poltak et al., 2015) dan tidak memerlukan biaya besar untuk di gunakan kotoran sapi dapat mengurangi biaya pengadaan pupuk yang sekaligus dapat mengurangi biaya produksi di samping menjaga kelestarian bahan organik sehingga dapat meningkatkan pendapatan, ternak juga dapat berperan sebagai industri biologis sekaligus mampu meningkatkan produksi daging dan penyedia kompos. Hal ini sejalan dengan pendapat Chandra Indrawanto dan Atman (2017) menjelaskan secara rinci manfaat integrasi tanaman dan ternak, yaitu: (1) meningkatkan diversifikasi usaha terhadap kotoran ternak, (2) peningkatan nilai tambah dari tanaman atau hasi ikutannya, (3) mempunyai potensi mempertahankan kesehatan dan fungsi ekosistem, dan (4) mempunyai kemandirian usaha yang tinggi dalam penggunaan sumberdaya mengingat nutrisi dan energi saling mengalir antara tanaman dan ternak.

Berdasarkan uraian di atas, masih rendahnya produktivitas dan pendapatan maka secara tegasnya permasalahan yang perlu dirumuskan dalam penelitian ini adalah bagaimana pengaruh integrasi tanaman dan ternak sapi terhadap produktivitas tanaman dan bagaimana pengaruh integrasi tanaman dan ternak sapi terhadap peningkatan pendapatan petani, Pemilihan lokasi dilakukan di 3 (tiga) Desa yaitu Desa Partungko Naginjang, Desa Janji Martahan dan Desa Siparmahan di Kecamatan Harian, Kabupaten Samosir karena Desa ini mendapatkan bantuan ternak sapi dari pemerintah

Tujuan Penelitian untuk mengetahui pengaruh integrasi tanaman dan ternak sapi terhadap produktivitas tanaman dan peningkatan pendapatan petan di Kecamatan Harian, Kabupaten Samosir. Kegunaan penelitian adalah bahan informasi bagi pemerintah atau lembaga lainya di dalam menentukan kebijakannya di bidang pertanian. Sebagai bahan pertimbangan untuk mengambil keputusan bagi petani dalam melaksanakan usahatani yang berkelanjutan melalui integrasi tanaman dan ternak sapi guna meningkatkan pendapatan dan keberlanjutan usahataninya.

\section{Metode}

Penelitian dilakukan di tiga desa dalam satu kecamatan wilayah Kabupaten Samosir yang mendapat bantuan sapi dari pemerintah. Metode yang digunakan yaitu metode studi kasus. yang merupakan suatu metode 
penyelidikan atau penelitian secara mendalam dari suatu individu, kelompok atau institusi dengan tujuan untuk menentukan faktor-faktor ataupun hubungan antar faktor dari subjek yang diteliti (Sumanto, 1995). Populasi dalam penelitian ini adalah seluruh peserta integrasi tanaman dan ternak sapi di tiga desa di kecamatan Harian yaitu sebanyak 52 orang. Karena jumlah populas dibawah 100 maka seluruh populasi dijadikan sampel penelitian (Vincent, 1991). Sampel juga diambil dari petani yang bukan peserta integrasi tanaman dan ternak sapi sebagai pembanding sebanyak jumlah sampel peserta integrasi. Dengan demikian jumlah sampel dalam penelitian ini sebanyak 104 orang.

Data primer dikumpulkan melalui observasi dan wawancara dengan bantuan kuesioner terstruktur (Singarimbun \& Effendi 1984). Data sekunder berasal dari sumber informasi dan instansi-instansi yang terkait. data sekunder lainnya yang berkaitan. Selanjutnya data primer dan data sekunder dikelompokkan dan ditabulasi menurut variabel yang diamati, kemudian dianalisis secara kuantitatif.

Data yang diperoleh ditabulasikan dan dianalisis sebagai berikut: Analisis pendapatan usaha petani kentang menurut Soekartawi (2002) dapat dituliskan sebagai berikut:

$\pi=\mathrm{TR}-\mathrm{TC}$

dengan $\mathrm{TR}=\mathrm{Q} \times \mathrm{Pq} \mathrm{TC}=\mathrm{TVC}+\mathrm{TFC}$

Keterangan:

$\pi \quad=$ Pendapatan $(\mathrm{Rp})$

TR $\quad=$ Penerimaan $(\mathrm{Rp})$

$\mathrm{TC}=$ Total Biaya Produksi $(\mathrm{Rp})$

$\mathrm{Q} \quad=$ Jumlah produk yang dihasilkan

$\mathrm{Pq} \quad=$ Harga Produk $/ \mathrm{kg}(\mathrm{Rp})$

TVC = Total Variabel Cost

TFC = Total Fixed Cost

Data yang diperoleh dari lapangan terlebih dahulu ditabulasi kemudian dilakukan analisis statistik sesuai dengan hipotesis yang hendak diuji. Karena variabel independen berkategori dua yaitu petani peserta sistem pertanian terpadu tanaman - ternak sapi dan petani yang bukan peserta sistem pertanian terpadu tanaman - ternak sapi , maka uji statistik yang digunakan adalah uji beda t-test Independent (uji beda rata-rata dua sampel) dengan menggunakan rumus (Ghozali, 2011).

$$
t=\frac{\text { rata }- \text { rata sampel pertama } \sim \text { rata }- \text { rata sampel kedua }}{\text { standard error perbedaan rata }- \text { rata kedua sampel }}
$$

Dimana sampel pertama adalah petani peserta sistem pertanian terpadu tanaman - ternak sapi, dan sampel kedua adalah petani yang bukan peserta sistem pertanian terpadu tanaman- ternak sapi. Selanjutnya nilai t-hitung dibandingkan dengan t-tabel pada $\alpha 5 \%$.

\section{Hasil dan Pembahasan}

\subsection{Biaya Produksi}

Berdasarkan penggunaan faktor-faktor produksi yang digunakan dalam usahatani kentang diantaranya adalah bibit, pupuk dan tenaga kerja, maka dapat diketahui jumlah biaya produksi yang dikeluarkan petani dalam usahatani kentang, dalam hal ini biaya dihitung untuk satu kali musim tanam, sebagaimana disajikan pada Tabel 1 .

Tabel 1. Rata-rata Biaya Produksi per Musim Tanam Kentang di Kecamatan Harian (Rp.000)

\begin{tabular}{llrrrr}
\hline No & \multicolumn{2}{l}{ Komponen } & BiayaPer Petani & \multicolumn{3}{l}{ Per Hektar } \\
\cline { 2 - 6 } & Produksi & \multicolumn{1}{l}{ Peserta } & \multicolumn{2}{l}{ Bukan PesertaPeserta } & Bukan Peserta \\
\hline 1 & Bibit & $19.567,31$ & $18.589,23$ & 22.346 & $22.682,69$ \\
2 & Pupuk Organik & 0 & $6.331,43$ & 0 & $7.749,04$ \\
3 & Pupuk Anorganik & $5.488,29$ & $5.150,09$ & $6.147,36$ & $6.307,93$ \\
4 & Pestisida & $2.727,63$ & $2.562,95$ & $3.063,08$ & $3.136,78$ \\
5 & Tenaga Kerja & $13.843,69$ & $12.738,13$ & $15.554,09$ & $15.593,75$ \\
\hline Total & & $41.626,91$ & $45.371,83$ & $47.110,67$ & $55.470,19$ \\
\hline \multicolumn{5}{l}{ Sumber : Data Primer Diolah (2015) }
\end{tabular}

Berdasarkan Tabel 1 penggunaan faktor produksi per petani, terdapa perbedaan pada biaya produksi untuk peserta dan bukan peserta pemberian bantuan sapi. Biaya produksi yang digunakan pada peserta per petani sebesar Rp 41.626.910 sedangkan biaya produksi untuk bukan peserta/ petani sebesar Rp 45.371.830. Dalam perhitungan biaya produksi per Hektar untuk petani peserta $\mathrm{Rp}$ 47.110.670 dan bukan peserta sebesar Rp 55.470.190. Komponen biaya yang paling banyak berbeda adalah komponen biaya pupuk organik. Hal ini sesuai dengan penggunaan pupuk yang lebih banyak pada petani bukan peserta. Biaya pupuk organik untuk peserta per petani adalah 0 hal ini disebabkan bantuan ternak sapi yang diberikan menghasilkan kotoran sapi yang dapat digunakan sebagai pupuk organik yang diolah menjadi kompos yang dapat digunakan untuk kesuburan tanah, sedangkan petani bukan peserta harus membeli pupuk organik. Adanya kotoran sapi dapat mengurangi biaya penggadaan pupuk yang sekaligus dapat mengurangi biaya produksi di samping menjaga kelestarian bahan organik tanah. Berdasarkan penelitian Siswati dan Nizar (2012) bahwa Ternak mempunyai posisi yang strategis dalam system pertanian terpadu yakni melalui ternak selain diperoleh produksi utama berupa daging, juga akan diperoleh limbah berupa kotoran padat dan cair untuk pupuk organik dan biogas.

\subsection{Produksi, Produktivitas dan Pendapatan}

Produktivitas kentang yang dihasilkan petani dihitung dalam satu kali musim tanam, demikian juga biaya produksi yang dikeluarkan petani. Jumlah produksi kentang dan pendapatan petani di Kecamatan Harian disajikan pada Tabel 2 .

Tabel 2. Rata-rata Produksi dan Pendapatan Petani per Musim Tanam Kentang di Kecamatan Harian

\begin{tabular}{llcccc}
\hline \multirow{2}{*}{ No } & Uraian & Per Petani & \multicolumn{3}{c}{ Per Hektar } \\
\cline { 3 - 6 } & & Peserta & \multicolumn{2}{c}{ Bukan Peserta Peserta } & Bukan Peserta \\
\hline 1 & Produksi & 23,16 & 20,33 & 25,93 & 24,94 \\
& (Ton) & & & & \\
2 & Penjualan & 74.005 .980 & 64.943 .020 & 82.872 .260 & 79.668 .810 \\
& (Rp.) & & & & \\
3 & Biaya & 41.626 .910 & 45.371 .830 & 47.110 .670 & 55.470 .190 \\
& $\begin{array}{l}\text { Produksi (Rp) } \\
4\end{array}$ & & & & \\
Pendapatan & 32.379 .070 & 19.571 .190 & 35.761 .590 & 24.198 .620 \\
& (Rp) & & & &
\end{tabular}

Sumber : Data Primer Diolah (2015)

Berdasarkan Tabel 2. Produksi kentang per petani lebih tinggi pada petani peserta sistem pertanian terpadu dibandingkan bukan peserta. Produktivitas tanaman peserta sistem pertanian terpadu adalah 25,93 ton per Hektar, sedangkan produktivitas tanaman petani bukan peserta adalah 24,94 ton per Hektar. Hal ini terjadi karena penggunaan pupuk anorganik yang lebih rendah pada petani peserta sistem pertanian terpadu, sehingga produksi kentang petani masih lebih tinggi.

Biaya produksi yang digunakan peserta per petani sebesar Rp. 41.626.910 sedangkan biaya produksi bukan peserta per petani sebesar Rp 45.371.830. Biaya produksi yang digunakan bukan peserta per petani lebih besar karena pembelian biaya pupuk anorganik sedangkan peserta per petani tidak membeli pupuk organik. Berdasarkan hasil penelitian, bahwa pendapatan per petani peserta per satu kali musim tanam lebih tinggi dari pendapatan petani bukan peserta. Jumlah pendapatan per petani peserta dari usaha tani kentang adalah Rp. 32.379.070,- sedangkan pendapatan per petani bukan peserta adalah sebesar Rp.19.571.190 untuk lebih lengkapnya dapat dilihat di Tabel 2.

Pertanian terpadu tanaman kentang dengan menggunakan ternak sapi mampu meningkatkan pendapatan petani sehinga petani semakin sejahtera karena telah ada peningkatan pendapatan. Jika harga kentang turun petani masih punya penghasilan lain yaitu dari ternak sapi, yang setiap tahun dapat menghasilkan anak dan pupuk. Hal ini sesuai dengan hasil penelitian Tarmizi dan Safaruddin (2012) menyatakan bahwa Sistem Integrasi Padi Ternak (SIPT) berpengaruh terhadap pendapatan petani di Kabupaten Serdang Bedagai, dimana terdapat perbedaan yang signifikan antara pendapatan per hektar petan SIPT dengan pendapatan petani non SIPT

\subsection{Produktivitas Tanaman}

Hasil analisis Tabel 3, berdasarkan nilai t Equal variances assumed adalah 5,026 dengan probabilitas 0.00 , dapat disimpulkan bahwa rata-rata produktivitas lahan dengan tanaman kentang per musim tanam berbeda secara signifikan antara petani peserta dan bukan peserta. Perbedaaan produktivitas kentang adalah sebesar 0,99 ton per Ha.

Hasil penelitian menunjukkan bahwa produktivitas lahan petani peserta sistem pertanian terpadu lebih tinggi daripada produktivitas lahan bukan peserta, demikian juga dalam hal efisiensi penggunaan modal kerja, terutama pupuk, dimana usahatani sistem pertanian terpadu lebih efisien dibandingkan dengan usahatani bukan peserta sistem pertanian terpadu. Peningkatan produktivitas tanaman kentang sebesar $4 \%$. Interaksi antara ternak dan tanaman haruslah saling melengkapi, mendukung dan saling menguntungkan, sehingga dapat mendorong efisiensi produksi dan meningkatkan keuntungan hasi usahataninya, bahwa usahatani sistem pertanian terpadu tanaman dan ternak sapi meningkatkan produktivitas lahan. Hal ini sejalan menurut Gomiero and Giompietro (2001) ternak yang dikombinasikan dengan lahan-lahan pertanian dapat disesuaikan dengan keadaan tanaman.Dimana ternak tidak berkompetisi pada lahan yang sama, tanaman sebagai komponen utama dan ternak sebgai komponen kedua. 
Tabel 3. Independent Sampel Test Produktivitas Tanaman Sistem pertanian terpadu tanaman - ternak sapi dan bukan sistem pertanian terpadu tanamanternak sapi.

\begin{tabular}{|c|c|c|c|c|c|}
\hline \multirow[t]{2}{*}{ Variabel } & & $\begin{array}{l}\text { Levene's } \\
\text { Test for } \\
\text { Equality of } \\
\text { Variances }\end{array}$ & \multicolumn{3}{|c|}{$\begin{array}{l}\text { t-test for } \\
\text { Equality } \\
\text { of Means }\end{array}$} \\
\hline & & Sig. & $\mathrm{t}$ & $\begin{array}{l}\text { Sig. ( } \\
\text { tailed) }\end{array}$ & $\begin{array}{l}\text {-Mean } \\
\text { Difference }\end{array}$ \\
\hline \multirow[t]{2}{*}{$\begin{array}{l}\text { Produktivitas } \\
\text { (ton/Ha) }\end{array}$} & $\begin{array}{l}\text { Equal } \\
\text { variances } \\
\text { assumed }\end{array}$ & 3.293 & 5.026 & .000 & .98962 \\
\hline & $\begin{array}{l}\text { Equal } \\
\text { variances } \\
\text { not } \\
\text { assumed }\end{array}$ & & 5.026 & .000 & .98962 \\
\hline
\end{tabular}

Sumber : Analisis Data Diolah (2015)

\subsection{Pendapatan}

Hasil analisis perbedaan pendapatan petani dapat dilihat pada Tabel 4 . Hasil analisis menunjukkan nilai F-hitung levene's test 1,064 dengan probabilitas 0,305 karena probabilitas > 0,05, maka dapat disimpulkan bahwa variances populasi adalah sama. Berdasarkan nilai t Equal variances assumed adalah 14,005 dengan probabilitas 0,00, dapat disimpulkan bahwa rata-rata pendapatan per musim tanam berbeda secara signifikan antara petani peserta dan petani bukan peserta. Perbedaan pendapatan adalah sebesar Rp 11.562.968 per Ha.

Tabel 4. Independen Samples Test Pendapatan Produktivitas Tanaman Sistem pertanian terpadu tanaman - ternak sapi dan bukan sistem pertanian terpadu tanaman-ternak sapi.

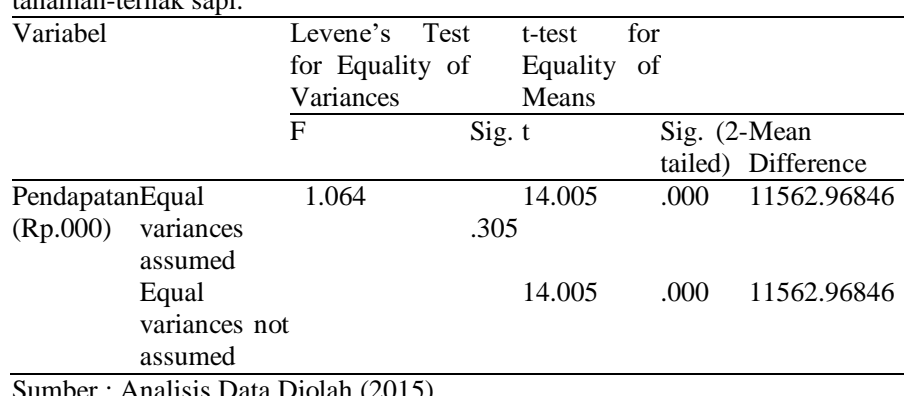

Sumber : Analisis Data Diolah (2015)

Hasil penelitian menunjukkan terdapat perbedaan pendapatan petani peserta dengan petani yang bukan peserta, dimana pendapatan petani peserta sistem pertanian terpadu per Ha lebih tinggi dibandingkan dengan petani bukan peserta. Berdasarkan hasil penelitian, faktor utama yang menyebabkan pendapatan petani peserta sistem pertanian terpadu lebih tinggi adalah karena biaya produksi usahataninya lebih rendah dibandingkan dengan petani bukan peserta sistem pertanian terpadu. Hal ini disebabkan karena peserta sistem pertanian terpadu memanfaatkan pupuk kompos berupa pupuk organik dari ternak sapi sehingga mengurangi penggunaan pupuk anorganik. Perbedaan biaya pupuk adalah sebesar Rp 316.380 per Ha, dengan demikian sistem pertanian terpadu tanaman - ternak sapi dapat menurunkan biaya pupuk sebesar Rp 316.380 per Ha.

Di Kecamatan Harian kebutuhan pupuk kompos untuk usahatani kentang yang dilakukan petani rata-rata 10 ton per Ha. dengan luas lahan petani peserta sistem pertanian terpadu rata-rata $0,89 \mathrm{Ha}$, maka kebutuhan kompos sebanyak 8,9 ton per musim tanam. Pola tanam kentang yang dilakukan petani di Kecamatan Harian adalah 3 kali dalam 2 tahun. Dengan demikian produksi kotoran sapi dapat mencukupi kebutuhan petani peserta, bahkan lebih karena kotoran sapi juga akan dikomposkan bersama sisa-sisa tanaman.

Menurut Sutanto (2002) beberapa manfaat penggunaan kompos dalam jangka panjang mampu meningkatkan N, P, K dan Si tanah, disamping itu juga mampu meningkatkan aktivitas mikrobia penyemat nitrogen melalui peningkatan kandungan bahan organik tanah yang mudah terdekomposisi, meningkatkan pembentukan agregat yang stabil dan pertukaran kation. Pemberian pupuk kandang dapat meningkatkan dan mempertahankan keanekaragaman dan kehidupan organisme tanah. Bahan organik merupakan sumber energi bagi kehidupan organisme tanah.

\section{Simpulan}

Pertanian terpadu tanaman dan ternak sapi berdampak signifikan terhadap peningkatan pendapatan petani di Kecamatan Harian, Kabupaten Samosir. Rata-rata pendapatan petani peserta pertanian terpadu per musim tanam lebih tinggi dibandingkan pendapatan petani bukan peserta, dengan perbedaan pendapatan sebesar Rp. 11.562.968 per Hektar. Pertanian terpadu tanaman dan ternak sapi berdampak signifikan terhadap peningkatan produktivitas lahan dengan tanaman kentang per musim tanam petani peserta pertanian terpadu lebih tinggi dibandingkan dengan petani bukan peserta, dengan perbedaan produktivitas lahan adalah sebesar 0,99 ton per Hektar.

\section{Pustaka}

Behera, U.K., Ytes, C.M., Kebreab, E, and J. France, 2008. Farming System ethology for Efficient Resource Management at the Farm Level: A Review from an Indian Perspective. Journal of Agricultural Sciense. 146. 493-505c.

Chandra Indrawanto dan Atman. 2017. Integrasi Tanaman-Ternak Solusi Meningkatkan Pendapatan Petani, IAARD PRESS, Badan Penelitian dan Pengembangan Pertanian, Jakarta.

Departemen Pertanian, 2005. Revitalisasi Pertanian, Perikanan dan Kehutanan, Departemen pertanian, Jakarta.

Direktorat Budidaya Ternak Ruminansia, 2010. Pedoman Teknis Pengembangan Integrasi Ternak Sapi dan Tanaman. Direktorat Jenderal Peternakan, Departemen Pertanian, Jakarta.

Ghozali, I. 2011. Aplikasi Analisis Multivariat dengan Program IBM SPSS 19, Edisi 5. BP Universitas Diponegoro, Semarang.

Gomiero, T and G, Mario. 2001. Multiple-ScaleIntegrated Analysis of Farming System The Thung Lo Cummune (Vietnamese Upland) Case Study Population ad Environment: A Journal of Interdisciplinary Studies 22 (3). 315-352.

Hendrickson, J, R., Hanson, J.D, Tanaka , Donald L. and G. Sassenrath. 2008 Principles of Integrated Agricultural System: Introduction to Processes and Definition. J. Renewable Agriculture and Food System.23(4):265 271.

Lubis, R. 2012. Analisis Dampak Intergrasi Tanaman dan Ternak Sapi Terhadap Pengembangan Wilayah di Kecamatan Harian Kabupaten Samosir. Thesis. Program PAsca Sarjana, Fakultas Pertanian, Universitas Sumatera Utara.

Poltak,S., Z. Lubis dan M. Sinaga. 2015. Analisis Sistem Integrasi Sapi Dan Kelapa Sawit Dalam Meningkatkan Pendapatan Petani Di Kabupaten Labuhan Batu, Agrica. Jurnal. Agribisnis Sumatera Utara Vol. 8 (1) :113.

Salikin, K.A. 2003. Sistem Pertanian Berkelanjutan, Kanisius.

Singarimbun, M. dan S. Effendi 1984. Metode Penelitian Survei. PT. LP3ES. Jakarta.

Siswati, L dan R, Nizar (2012). Model pertanian terpadu tanaman hortikultura dan ternak sapi untuk meningkatkan pendapatan petani. J. Peternakan Indonesia. 14(2):379-384.

Soekartawi. 2002. Prinsip Dasar Ekonomi Pertanian. Penerbit PT Raja Grafindo Persada, Jakarta.

Sumanto. 1995. Metodologi Penelitian Sosial dan Pendidikan. Penerbit Andi Offset, Yogyakarta.

Sutanto, R. 2002. Pertanian Organik. Kanisius, Yogyakarta.

Tarmizi, H,B dan Safaruddin. 2012. Pengaruh sistem integrasi padi ternak (sipt) terhadap peningkatan pendapatan petani dan dampaknya terhadap pengembangan wilayah di kabupaten serdang bedagai. J. Ekonom. 15(4):163-172.

Tracy, B, F dan A, S, Davis. 2009. Weed Biomass and Species Composition as Affected by an Integrated Crop- Livestock System. Crop Science, Vol. 49. 1523-1530.

Vincent, G. 1991. Teknik Penarikan Contoh Untuk Penelitian Survei, Penerbit Tarsito, Bandung. 